\title{
Phosphofructokinase and the Regulation of the Flux of Carbon from Glucose to Lipid in the Oleaginous Yeast Rhodosporidium toruloides
}

\author{
By CHRISTOPHER T. EVANS $\uparrow$ AND COLIN RATLEDGE* \\ Department of Biochemistry, University of Hull, Hull HU6 7RX, UK
}

(Received 3 January 1984; revised 2 August 1984)

Changes in cell composition of Rhodosporidium toruloides CBS 14 were monitored during growth of batch cultures with $\mathrm{NH}_{4} \mathrm{Cl}$ and glutamate as nitrogen sources. Carbohydrate was synthesized at the expense of lipid in $\mathrm{NH}_{4}^{+}$-grown cells, whereas in glutamate-grown cells lipid accumulation was predominant. Total biomass and protein concentration were similar in both cultures. Uptake of $\left[\mathrm{U}^{-14} \mathrm{C}\right],\left[1-{ }^{14} \mathrm{C}\right]$ and $\left[6-{ }^{14} \mathrm{C}\right] \mathrm{glucose}$, and evolution of ${ }^{14} \mathrm{CO}_{2}$ from these sources, by washed suspensions of cells grown on glutamate revealed the flux of carbon during glucose dissimilation was principally via the Embden-Meyerhof pathway $(72 \%)$, with $28 \%$ being metabolized by the pentose phosphate pathway. Both urea and glutamate, when added to the cell suspensions, significantly stimulated glucose catabolism, with the flux of carbon via the former pathway increasing to about $89 \%$ of the total. Phosphof ructokinase (PFK) was implicated as the likely controlling enzyme to explain these events.

PFK was only detected in extracts prepared from the yeast grown in a carbon-limited (nitrogen-excess) medium; no activity was detected in extracts of cells grown in nitrogen-limited medium. The presence of a protease in these latter extracts was revealed. PFK was purified 92fold to a final specific activity (in the presence of $10 \mathrm{~mm}^{-\mathrm{NH}_{4}^{+}}$) of 4.2 units (mg protein) ${ }^{-1}$ and exhibited one broad band on polyacrylamide gel electrophoresis. The apparent mol. wt $\left(M_{\mathrm{r}}\right)$ of the enzyme was approx. 700000. The major properties of the enzyme were examined to determine its regulatory role during lipid biosynthesis. Unlike the enzyme from Saccharomyces cerevisiae, no inhibition was found with $10 \mathrm{~mm}$-ATP. ADP was not inhibitory either. $\mathrm{NH}_{4}^{+}$ions increased activity 11-fold by increasing the affinity of the enzyme for both fructose 6-phosphate and ATP. $\mathrm{K}^{+}$ions also stimulated activity but to a lesser extent. Activity was severely inhibited by citrate, isocitrate and cis-aconitate but this inhibition was dramatically alleviated by $\mathrm{NH}_{4}^{+}$. Inhibition by citrate was competitive with fructose 6-phosphate in the absence of $\mathrm{NH}_{4}^{+}$ions. The $K_{\mathrm{i}}$ values for citrate were $1.0 \mathrm{mM}$ (with no $\mathrm{NH}_{4}^{+}$) and $7.2 \mathrm{~mm}$ (with $10 \mathrm{mM}-\mathrm{NH}_{4}^{+}$). Long-chain fatty acyl-CoA esters had no significant inhibitory effect. It is concluded that the interplay between the prevailing intracellular concentrations of $\mathrm{NH}_{4}^{+}$and citrate is the major determinant of the activity of PFK in vivo and thus governs the extent to which glucose is converted either to lipid or carbohydrate.

\section{INTRODUCTION}

Until recently, investigations into the control of lipid accumulation by yeasts have compared various aspects of metabolism in oleaginous yeasts with those in non-oleaginous species (Botham \& Ratledge, 1979; Boulton \& Ratledge, 1981). However, recently we have examined the effect of the medium nitrogen source on lipid accumulation, as it had previously been reported that certain yeasts could accumulate substantially more lipid when various organic nitrogen sources, rather than $\mathrm{NH}_{4}^{+}$, were used for growth (see for example Blinc \& Hočevar, 1953;

† Present address: Allelix Inc., Mississauga, Ontario L4V 1P1, Canada.

Abbreviations: FACE, fatty acyl-coenzyme A ester; F6P, fructose 6-phosphate; PFK, phosphofructokinase. 
Witter et al., 1974). By screening numerous yeasts for lipid accumulation with several different nitrogen sources, we were able to confirm these early reports and identify a small number of yeasts that could produce different amounts of lipid depending on the nitrogen source (Evans \& Ratledge, 1984a). We chose the yeast Rhodosporidium toruloides CBS 14 for all subsequent work, as its lipid content was shown to vary from $18 \%(\mathrm{w} / \mathrm{w})$, when grown with $\mathrm{NH}_{4}^{+}$as nitrogen source, to $52 \%(\mathrm{w} / \mathrm{w})$ when glutamate or urea was used (Evans \& Ratledge, 1984a,b).

This yeast therefore provided us with a system of lipid accumulation in which the lipid content could be controlled by just one factor, namely the nature of the nitrogen source used in the medium. We have shown, using this yeast, that nitrogen metabolism and lipid biosynthesis are intimately linked. The production of $\mathrm{NH}_{4}^{+}$ions intracellularly, as a result of catabolism of the nitrogen source, correlates well with the increased synthesis of citric acid (the precursor of the cytosolic acetyl-CoA essential for lipid production) (Evans \& Ratledge, 1984a, b). In an attempt to determine the nature of the interaction of the products of nitrogen catabolism with lipid biosynthesis, we have examined the influence of the nitrogen source on the synthesis of major cellular components, and from this have gone on to investigate the effect of the nitrogen sources on the flux of carbon through the two major pathways of glucose dissimilation: the EmbdenMeyerhof pathway and the pentose phosphate pathway, which are known to be the predominant pathways for glucose metabolism in this yeast (Mazon et al., 1974; Ratledge \& Botham, 1977). The results we obtained suggested that phosphofructokinase (PFK) could play a key role in regulating the flow of carbon through the glycolytic pathway with its activity in vivo being controlled by the choice of nitrogen source used in the growth medium.

PFK is, of course, well-established as a key regulatory enzyme in almost all organisms, including yeasts (Fraenkel, 1982; Uyeda, 1979). We therefore undertook the purification and study of the properties of this enzyme from Rs. toruloides. The enzyme was originally thought to be absent in this yeast (syn. Rhodotorula glutinis) (Höfer et al., 1971) but was subsequently identified using carefully controlled conditions of assay (Mazon et al., 1974). In the course of this work we have found that there is a protease, possibly specific for PFK hydrolysis, within the yeast which could account for the lability of previous preparations.

\section{METHODS}

Yeast and growth conditions. Rhodosporidium toruloides CBS 14 was grown on the basal medium as previously described by Evans \& Ratledge (1984a) with glucose at $30 \mathrm{~g} \mathrm{l}^{-1}$ and $\mathrm{NH}_{4} \mathrm{Cl}$ at $0.5 \mathrm{~g} \mathrm{l}^{-1}$ for nitrogen-limited medium, and with glucose at $12 \mathrm{~g} \mathrm{l}^{-1}$ and $\mathrm{NH}_{4} \mathrm{Cl}$ at $3.0 \mathrm{~g} \mathrm{l}^{-1}$ for carbon-limited medium.

Analyses. Biomass and lipid were determined by procedures given previously (Evans \& Ratledge, 1983). Total cell protein was determined using the biuret method as described by Herbert et al. (1971) using $5 \mathrm{mg}$ freezedried cells suspended in $0.5 \mathrm{ml}$ water. Total cell carbohydrate was determined by the phenol $/ \mathrm{H}_{2} \mathrm{SO}_{4} \mathrm{method}$ described by Herbert et al. (1971) using $10 \mathrm{mg}$ freeze-dried cells (20 to $100 \mu \mathrm{g}$ glucose equivalents).

Determination of individual polysaccharides. Trehalose, glucan and mannan were determined by the method of Trevelyan \& Harrison (1956) using 5\% phenol. Glycogen was determined using amyloglucosidase by the method of Gunja-Smith et al. (1977). Intracellular extracts for metabolite assay were prepared as described previously (Evans \& Ratledge, 1984a).

Incorporation of radioactivity. Uptake of $\left[\mathrm{U}^{-14} \mathrm{C}\right],\left[1^{-14} \mathrm{C}\right]$ and $\left[6^{-14} \mathrm{C}\right] \mathrm{glucose}$ (Amersham) into lipid and evolution of ${ }^{14} \mathrm{CO}_{2}$ by cell suspensions of $R$ s. toruloides was followed using the procedure described by Ratledge $\&$ Botham (1977). Cells for the experiment had been grown on glucose/glutamate medium for $30 \mathrm{~h}$. Incubations, at $30{ }^{\circ} \mathrm{C}$, were started by adding $200 \mu \mathrm{l}$ of radiolabelled glucose solution, containing $3 \mathrm{mg}$ glucose with $3 \mu \mathrm{Ci}$ $(111 \mathrm{kBq})$ activity, into each sealed Warburg flask. One flask was used for each separate determination with the reaction being stopped by adding $\mathrm{H}_{2} \mathrm{SO}_{4}$ from the side-arm of the flask. Suspensions were neutralized with $\mathrm{KOH}$ before freeze-drying and extracting the lipid. The radioactivity in the lipid and the filter paper, placed in the central well of the flask to trap ${ }^{14} \mathrm{CO}_{2}$, was counted by liquid scintillation. The percentage carbon flux through the pentose phosphate cycle and, by difference, the amount through the Embden-Meyerhof pathway, was calculated using the formula of Wood et al. (1963):

$$
\frac{{ }^{14} \mathrm{C} \text { in triose phosphate derivative (i.e. lipid) from }\left[1{ }^{14} \mathrm{C}\right] \mathrm{glucose}}{{ }^{14} \mathrm{C} \text { in triose phosphate derivative from }\left[6^{-14} \mathrm{C}\right] \mathrm{glucose}}=\frac{1-\mathrm{PC}}{1+2 \mathrm{PC}}
$$

where PC $=$ pentose phosphate cycle. 
Preparation of cell extracts. Cells were washed twice with $100 \mathrm{~mm}-\mathrm{KH}_{2} \mathrm{PO}_{4} / \mathrm{Na}_{2} \mathrm{HPO}_{4}$ buffer, $\mathrm{pH} 7 \cdot 8$, and were usually disrupted by a single passage through a pre-cooled French pressure cell at $35 \mathrm{MPa}$ (cf. Evans \& Ratledge, 1983). Cells were also disrupted ultrasonically (cf. Hughes et al., 1971) or by forming sphaeroplasts with Zymolyase 6000 (Miles Laboratories, Stoke Poges, Bucks., UK) which were then subsequently broken by gentle shaking. Cells were also lysed with toluene (Serrano et al., 1973) in order to assay phosphofructokinase in situ (cf. Ratledge \& Botham, 1977).

Determination of protein concentration. This was done by the dye-binding method of Bradford (1976) using bovine $\gamma$-globulin as standard.

Enzyme assay. 6-Phosphofructokinase (EC 2.7.1.11) (PFK) was assayed by the method of Sols \& Salas (1966) using the coupled enzyme spectrophotometric procedure with ATP as co-substrate and potassium phosphate buffer at $\mathrm{pH} 8 \cdot 0$. The coupling enzymes (aldolase, triosephosphate isomerase and $\alpha$-glycerophosphate dehydrogenase) were desalted to remove $\left(\mathrm{NH}_{4}\right)_{2} \mathrm{SO}_{4}$, which is a positive effector of $\mathrm{PFK}$, by dialysis before use.

Purification of $P F K$. All procedures were carried out at $4{ }^{\circ} \mathrm{C}$. The yeast was cultivated on carbon-limiting medium and washed in an extraction buffer containing $100 \mathrm{mM}-\mathrm{KH}_{2} \mathrm{PO}_{4} / \mathrm{Na}_{2} \mathrm{HPO}_{4} \mathrm{pH} 7 \cdot 8,100 \mathrm{mM}-\mathrm{KCl}$, $10 \mathrm{mM}$-mercaptoethanol, $1 \mathrm{mM}$-fructose 6-phosphate and $100 \mathrm{mg}$ phenylmethylsulphonyl fluoride (PMSF) $\mathrm{l}^{-1}$ as a protease inhibitor. The cell-free extract was prepared by a single passage through a pre-cooled French pressure cell at $35 \mathrm{MPa}$ and centrifuged at $43000 \mathrm{~g}$ for $30 \mathrm{~min}$.

A freshly prepared suspension of protamine sulphate $(1.5 \%$, w/v), adjusted to $\mathrm{pH} 6.4$ with $\mathrm{KOH}$, was added to the crude extract to give a final ratio of $1 \mathrm{mg}$ protamine sulphate to $12 \mathrm{mg}$ protein. The precipitate was then removed by centrifugation at $30000 \mathrm{~g}$ for $20 \mathrm{~min}$ and discarded. Fractionation with $\left(\mathrm{NH}_{4}\right)_{2} \mathrm{SO}_{4}$ was carried out, collecting the fraction precipitating between 39 and $49 \%$ saturation. This precipitate was collected and dissolved in buffer (no. 2) containing: $50 \mathrm{~mm}-\mathrm{KH}_{2} \mathrm{PO}_{4} / \mathrm{Na}_{2} \mathrm{HPO}_{4} \mathrm{pH} 7.8,5 \mathrm{mM}-\mathrm{MgCl}_{2}, 1 \mathrm{~mm}$-EDTA, $5 \mathrm{~mm}$-mercaptoethanol, $1 \mathrm{~mm}$-fructose 6-phosphate and $100 \mathrm{mg} \mathrm{l}^{-1} \mathrm{PMSF}$. The suspension was subjected to a second $\left(\mathrm{NH}_{4}\right)_{2} \mathrm{SO}_{4}$ fractionating, collecting the fraction precipitating between 44 and $53 \%$ saturation. The precipitate was collected and dissolved in buffer no. 2 .

The enzyme solution was applied to a column of Sephadex G-200 $(2.5 \times 38 \mathrm{~cm})$ equilibrated with buffer no. 2 . After elution with the same buffer, the fractions containing PFK activity were pooled and eluate applied directly to a column of DEAE-cellulose (DE-52) $(2.5 \times 35 \mathrm{~cm})$ equilibrated in buffer no. 2 . The column was eluted with the same buffer until the eluate was free of protein (monitored at $280 \mathrm{~nm}$ ).

A continuous gradient of $\mathrm{KCl}(0$ to $300 \mathrm{mM}$ ) in buffer no. 2 was used to elute the enzyme which appeared between 40 to $80 \mathrm{~mm}-\mathrm{KCl}$. This fraction was pooled, and solid $\left(\mathrm{NH}_{4}\right)_{2} \mathrm{SO}_{4}$ added to give $50 \%$ saturation. The precipitate was dissolved in $5 \mathrm{ml}$ buffer no. 2 and applied to a column of Sepharose-6B $(3.5 \times 50 \mathrm{~cm})$ equilibrated with buffer no. 2 . The elution profile showed a single main protein peak which contained all the PFK activity. The pooled Sepharose-6B eluate was concentrated over an Amicon PM10 membrane to a $5 \mathrm{ml}$ volume and stored at $-20{ }^{\circ} \mathrm{C}$ in $10 \mathrm{~mm}-\left(\mathrm{NH}_{4}\right)_{2} \mathrm{SO}_{4}$ and $1 \mathrm{~mm}$-fructose 6-phosphate.

Determination of purity of $P F K$ preparation. Samples of the concentrated enzyme, containing approximately 50 to $100 \mu \mathrm{g}$ protein, were developed at $4{ }^{\circ} \mathrm{C}$ on $5 \%(\mathrm{w} / \mathrm{v})$ polyacrylamide gels, according to the procedure of Davis (1964) in 0.04 M-Tris/glycine buffer, pH 8.3 at $5 \mathrm{~mA}$ per tube. Protein was detected by staining for $3 \mathrm{~h}$ in Serva Blue G ( $1 \%$ Serva Blue G in $12 \%$ TCA; Serva Feinbiochimica, Heidelberg, FRG). No destaining was necessary.

Calibration of Sepharose- $6 B$ column for determination of molecular size of PFK. A column of Sepharose-6B $(3.5 \times$ $50 \mathrm{~cm}$ ) was equilibrated with $50 \mathrm{mM}-\mathrm{KH}_{2} \mathrm{PO}_{4} / \mathrm{Na}_{2} \mathrm{HPO}_{4}$ buffer $\mathrm{pH} 7 \cdot 8$. The void volume of the column was determined using blue dextran (Pharmacia). The following proteins were loaded on to the column in a total volume of $2.8 \mathrm{ml}$ and eluted in the above buffer: urease, $\beta$-galactosidase, arginine decarboxylase, pyruvate kinase, aldolase and malate dehydrogenase. Thyroglobulin was run separately and assayed spectrophotometrically at $280 \mathrm{~nm}$. The other proteins were detected by appropriate enzyme assays.

\section{RESULTS}

\section{Change in cell composition during growth of Rs. toruloides in batch culture}

When $R$ s. toruloides CBS 14 had been previously grown on glutamate as nitrogen source, the lipid content increased to over $50 \%$ of the biomass, compared to less than $20 \%$ when $\mathrm{NH}_{4} \mathrm{Cl}$ had been used (Evans \& Ratledge, 1984a). However, the $\mathrm{NH}_{4}^{+}$-grown cells still assimilated glucose and grew to the same yield as the glutamate grown cells; a detailed analysis of lipid, carbohydrate and protein contents of the two types of culture was therefore carried out to discover the nature of the material which these cells must be accumulating instead of lipid (Fig. 1).

During the first $30 \mathrm{~h}$ growth, that is up to the exhaustion of the nitrogen source from the medium, cells of both cultures had the same gross composition. However, after $30 \mathrm{~h}$ there was a marked divergence in accumulation of carbohydrate and lipid though the protein content of the 

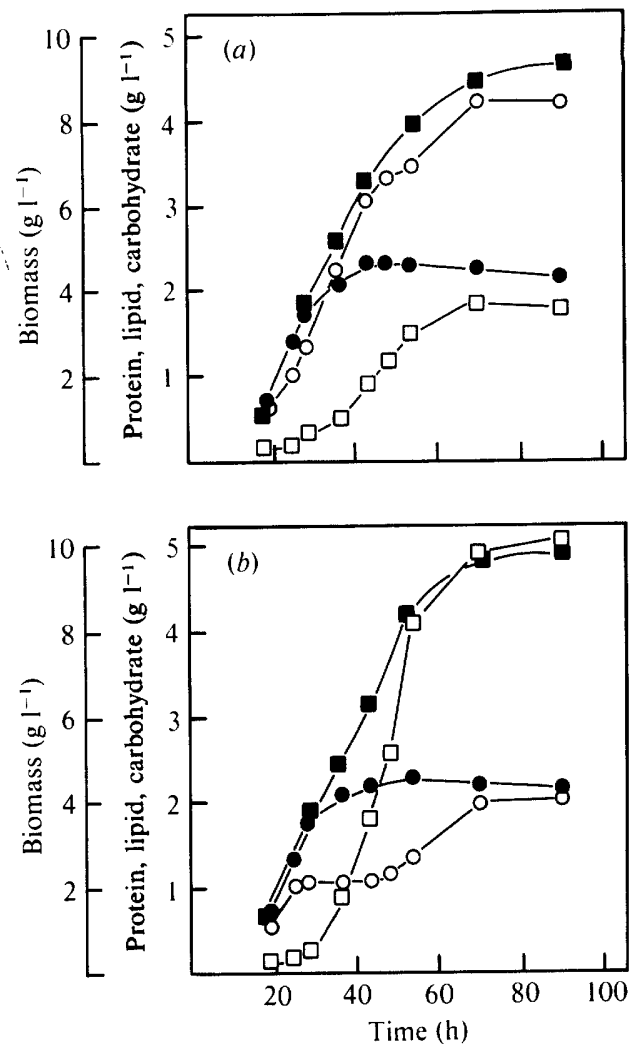

Fig. 1. Changes in cell composition of Rs. toruloides CBS 14 during batch culture with growth on (a) $\mathrm{NH}_{4} \mathrm{Cl}$ and $(b)$ glutamate as nitrogen sources. $\square$, Biomass; $\bigcirc$, carbohydrate; $\bigcirc$, protein; $\square$, lipid. Nitrogen (not shown) was exhausted from both media after 24 to $28 \mathrm{~h}$.

two cultures throughout growth was almost the same: at the end of growth $(90 \mathrm{~h}) \mathrm{NH}_{4}^{+}$-grown cells contained $23 \%$ protein, whereas glutamate-grown cells had $20 \%$. The carbohydrate and lipid contents showed a strong, reciprocal relationship between the two types of cells with the $\mathrm{NH}_{4}^{+}$-grown cells finally having over twice the carbohydrate (42\% compared to $20 \%$ ) but less than half the lipid ( $21 \%$ compared to $51 \%$ ) of the glutamate-grown cells. These results suggested there might be an interplay between the lipid and carbohydrate synthesizing systems, viz:

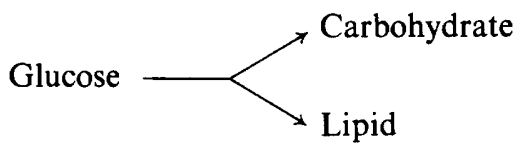

Any block in the synthesis of one component would then divert the incoming carbohydrate into the other. The existence of such an interplay would then fit in with the previously observed rise in the concentration of glucose 6-phosphate in $\mathrm{NH}_{4}^{+}$-grown cells where, after $60 \mathrm{~h}$ growth, the concentration was twice that in glutamate-grown cells (Evans \& Ratledge, 1984a).

The additional (accumulating) carbohydrate in the $\mathrm{NH}_{4}^{+}$-grown cells appeared to be mainly glycogen - both acid- and alkali-soluble. These cells contained $26 \%$ glycogen compared to only $11 \%$ in glutamate-grown cells; trehalose content was approximately the same in both types of cell $(6.6 \%$ and $6.2 \%)$ with mannan plus glucan accounting for $5.6 \%$ and $2.2 \%$, respectively.

If this view of a switch in metabolism were correct, we would expect to see changes in the flux of carbon to lipid via the major pathways of metabolism: the Embden-Meyerhof pathway and the pentose phosphate pathway, according to the nature of the nitrogen source which was used. 
Table 1. Incorporation of radiolabelled glucose into lipid, and ${ }^{14} \mathrm{CO}_{2}$ evolution by cell suspensions of Rs. toruloides

See Methods for incubation conditions. Each line represents a single flask.

\begin{tabular}{|c|c|c|c|c|c|c|c|c|}
\hline \multirow{3}{*}{$\begin{array}{l}\text { Nitrogen source } \\
(20 \mathrm{mM}) \text { added to } \\
\text { incubation mixture }\end{array}$} & \multicolumn{6}{|c|}{ Radioactivity incorporated from: } & \multicolumn{2}{|c|}{$\%$ Flux through $\neq:$} \\
\hline & \multicolumn{2}{|c|}{$\left[\mathrm{U}-{ }^{14} \mathrm{C}\right]$ Glucose } & \multicolumn{2}{|c|}{$\left[1-^{14} \mathrm{C}\right]$ Glucose } & \multicolumn{2}{|c|}{$\left[6^{-14} \mathrm{C}\right]$ Glucose } & & \\
\hline & Lipid* & ${ }^{14} \mathrm{CO}_{2} \dagger$ & Lipid* & ${ }^{14} \mathrm{CO}_{2} \dagger$ & Lipid* & ${ }^{14} \mathrm{CO}_{2} \dagger$ & pathway & pathway \\
\hline None & 1508 & 420 & 979 & 280 & 2152 & 40 & 28 & 72 \\
\hline None & 1083 & 462 & 1099 & 295 & 2594 & 62 & 31 & 69 \\
\hline $\mathrm{NH}_{4} \mathrm{Cl}$ & 994 & 497 & 1132 & 309 & 2490 & 21 & 29 & 71 \\
\hline $\mathrm{NH}_{4} \mathrm{Cl}$ & 1348 & 483 & 1309 & 314 & 2542 & 39 & 24 & 76 \\
\hline L-Glutamate & 2687 & 747 & 2243 & 465 & 3072 & 109 & 11 & 89 \\
\hline L-Glutamate & 2605 & 799 & 2112 & 394 & 3019 & 83 & 13 & 87 \\
\hline L-Glutamate & 2533 & 712 & 2898 & 378 & 3683 & 88 & 8 & 92 \\
\hline L-Glutamate & 1227 & 694 & 1982 & 402 & 2804 & 94 & 12 & 88 \\
\hline Urea & 1979 & 637 & 3004 & 398 & 4243 & 122 & 12 & 88 \\
\hline Urea & 2853 & 702 & 2529 & 377 & 3416 & 97 & 10 & 90 \\
\hline
\end{tabular}

We therefore investigated the effect of glutamate and $\mathrm{NH}_{4}^{+}$upon the pathways of glucose catabolism and of lipogenesis in glutamate-grown cells (Table 1). Glutamate-grown cells were used in preference to $\mathrm{NH}_{4}^{+}$-grown cells as they possess an active $\mathrm{NAD}^{+}$-glutamate dehydrogenase which is repressed in the latter cells (Evans \& Ratledge, 1984a). Addition of glutamate to cell suspensions of $\mathrm{NH}_{4}^{+}$-grown cells would therefore have little immediate effect on lipogenesis or on the fluxes of glucose metabolism as it is, in all probability, the prevailing intracellular concentration of $\mathrm{NH}_{4}^{+}$which is the important metabolic regulator, rather than glutamate per se. Addition of glutamate (or urea) to glutamate-grown cells, on the other hand, would quickly lead to increases in the intracellular $\mathrm{NH}_{4}^{+}$concentrations. The incorporation of ${ }^{14} \mathrm{C}$ into lipid was measured as this gives an indirect measure of the formation of acetyl-CoA as the end-product of glucose catabolism from which the proportion of glucose metabolized by the pentose phosphate pathway can be calculated (see Wood et al., 1963). Evolution of ${ }^{14} \mathrm{CO}_{2}$ was also followed. However, it is not possible to calculate the percentage contribution of the pentose phosphate pathway from such data unless the specific yield of ${ }^{14} \mathrm{CO}_{2}$ per amount glucose utilized can be determined (Wood et al., 1963) and this was not done. Comparison of the ${ }^{14} \mathrm{CO}_{2}$ evolution values nevertheless provide a qualitative guide as to changes in the amount of glucose being metabolized by both the pentose phosphate and the Embden-Meyerhof pathways.

The incorporation of ${ }^{14} \mathrm{C}$ into lipid from $\left[\mathrm{U}-{ }^{14} \mathrm{C}\right]$ glucose was only slightly higher than that from $\left[1-{ }^{14} \mathrm{C}\right]$ glucose but both were substantially less than that from $\left[6-{ }^{14} \mathrm{C}\right]$ glucose. Rates of incorporation, measured over the $60 \mathrm{~min}$ incubation (data not shown), were reasonably constant. Addition of $\mathrm{NH}_{4}^{+}$gave no increase in the incorporation of ${ }^{14} \mathrm{C}$ from any of the three labelled glucoses. Glutamate, and also urea, when added to the cell suspensions, produced large increases with all three labelled glucoses, with the effect being strongest with both $\left[\mathrm{U}-{ }^{14} \mathrm{C}\right]$ and $\left[1-{ }^{14} \mathrm{C}\right]-$ glucose. Again, the increases caused by glutamate and urea were reasonably constant over the whole of the incubation period (not shown). The proportion of glucose being metabolized via the Embden-Meyerhof pathway in the presence of glutamate or urea was calculated as between 87 and $92 \%$, compared with between 69 and $76 \%$ in their absence or in the presence of $\mathrm{NH}_{4}^{+}$ (Table 1).

Evolution of ${ }^{14} \mathrm{CO}_{2}$ from the three labelled glucoses also showed reasonably constant rates over $60 \mathrm{~min}$ incubation (data not shown). Analysis after $60 \mathrm{~min}$ (Table 1) showed that $\mathrm{NH}_{4}^{+}$produced little, if any, significant increase and, with $\left[6^{-14} \mathrm{C}\right]$ glucose, appeared, if anything, to depress ${ }^{14} \mathrm{CO}_{2}$ evolution slightly. Both glutamate and urea stimulated the evolution of ${ }^{14} \mathrm{CO}_{2}$ from 
Table 2. Purification of phosphofructokinase from Rs. toruloides CBS 14

\begin{tabular}{|c|c|c|c|c|c|}
\hline Step & $\begin{array}{l}\text { Total activity } \\
\left(\mu \mathrm{mol} \mathrm{min}^{-1}\right)\end{array}$ & $\begin{array}{l}\text { Total protein } \\
(\mathrm{mg})\end{array}$ & $\begin{array}{c}\text { Specific activity } \\
\left(\mathrm{nmol} \mathrm{mg}^{-1} \mathrm{~min}^{-1}\right)\end{array}$ & $\begin{array}{c}\text { Recovery } \\
(\%)\end{array}$ & $\begin{array}{l}\text { Purification } \\
\quad \text { (fold) }\end{array}$ \\
\hline Crude & 94.95 & 1899 & 50 & 100 & 1 \\
\hline Protamine sulphate & $81 \cdot 84$ & 880 & 93 & 86 & $1 \cdot 8$ \\
\hline $\begin{array}{l}\left(\mathrm{NH}_{4}\right)_{2} \mathrm{SO}_{4} \text { precipitation } \\
(39-49 \%)\end{array}$ & $53 \cdot 16$ & 194 & 274 & 56 & $5 \cdot 4$ \\
\hline $\begin{array}{l}\left(\mathrm{NH}_{4}\right)_{2} \mathrm{SO}_{4} \text { precipitation } \\
\quad(44-53 \%)\end{array}$ & $45 \cdot 9$ & 58 & 792 & 48 & $15 \cdot 9$ \\
\hline Sephadex G-200 & $42 \cdot 2$ & 30 & 1408 & 44 & $28 \cdot 2$ \\
\hline DEAE-cellulose (DE-52) & 34.9 & 12 & 2917 & 35 & $58 \cdot 3$ \\
\hline Sepharose 6B & 27.6 & 6 & 4619 & 28 & $92 \cdot 4$ \\
\hline
\end{tabular}

all three labelled glucoses, indicating that there was an increase in the total amount of glucose now being catabolized by the two pathways. The figures for ${ }^{14} \mathrm{CO}_{2}$ evolution from $\left[\mathrm{U}-{ }^{1+} \mathrm{C}\right]-$ glucose would indicate that this increase could be as much as $70 \%$; the figures for ${ }^{14} \mathrm{CO}_{2}$ release from $\left[6-{ }^{14} \mathrm{C}\right]$ glucose, where the radiolabel would not be lost until after the level of pyruvate had been reached, would support this estimate.

We would interpret these results as follows. Growth of $R s$, toruloides on glucose with $\mathrm{NH}_{4}^{+}$as nitrogen source has a restricted flow of carbon through both the Embden-Meyerhof and pentose phosphate pathways. Consequently, incoming glucose is channelled more into reserve carbohydrates than into lipid even though this yeast has the necessary metabolic machinery to effect lipid accumulation. In the presence of an organic source of nitrogen (see Evans \& Ratledge, $1984 b$ ), such as glutamate or urea, the metabolic impediment to glucose catabolism is removed and more glucose is now able to reach the level of citrate and hence acetyl-CoA and lipid. As this increase in throughput of glucose to lipid corresponds with the previously noted depletion in glucose 6-phosphate concentration (Evans \& Ratledge, 1984a) and, with an increased percentage of glucose now flowing through the Embden-Meyerhof pathway (Table 1), it seems reasonable to suppose that the principal controlling enzyme would be PFK. Previous studies (Evans \& Ratledge, 1984a, b) have shown that the intracellular concentrations of $\mathrm{NH}_{4}^{+}$are highest when organic compounds are used as nitrogen sources and are lowest when $\mathrm{NH}_{4}^{+}$salts are used. As the controlling influence of $\mathrm{NH}_{4}^{+}$on the activity of PFK in other yeasts is well-established (Sols et al., 1971; Uyeda, 1979) the importance of this enzyme in Rs. toruloides was investigated.

\section{$P F K$ in crude extracts}

Despite numerous attempts to stabilize it, only very low activity of PFK could be detected in crude extracts prepared by a variety of means (see Methods) from cells grown in nitrogen-limiting (lipid accumulating) medium. Such lability had also been encountered by Mazon et al. (1974), and in another oleaginous yeast, Candida 107, by Ratledge \& Botham (1977), who finally used yeast cells made permeable with toluene to demonstrate PFK activity. Toluenepermeabilization also worked with Rs. toruloides but subsequent disruption of these cells led to a rapid loss of activity. However, activity could be detected in extracts of $R s$. toruloides grown on carbon-limiting medium. When extracts from these cells were mixed $(1: 1)$ with ones from cells grown in nitrogen-limiting medium, PFK activity was lost within $30 \mathrm{~min}$ incubation at $30^{\circ} \mathrm{C}$. This inactivation was prevented by adding PMSF as an inhibitor of proteolytic activity (Holzer et al., 1975). The protease present in the nitrogen-limited extract appeared to be somewhat specific for PFK as activity of other large molecular weight enzymes (ATP:citrate lyase, $\mathrm{NAD}^{+}$-isocitrate dehydrogenase and aldolase) from this yeast were not affected.

\section{Purification of phosphofructokinase}

PMSF was used as protease inhibitor in all buffers throughout the purification. The procedure used for purifying PFK (Table 2 ) gave a 92 -fold purification with a $28 \%$ recovery. PFK eluted as a single sharp peak of activity following gel filtration through Sepharose $6 \mathrm{~B}$. When $50 \mu \mathrm{l}$ of this preparation was subjected to polyacrylamide disc gel electrophoresis and stained with Serva Blue for $3 \mathrm{~h}$, only a single band of protein was detected; after a further $7 \mathrm{~h}$ staining, three very 


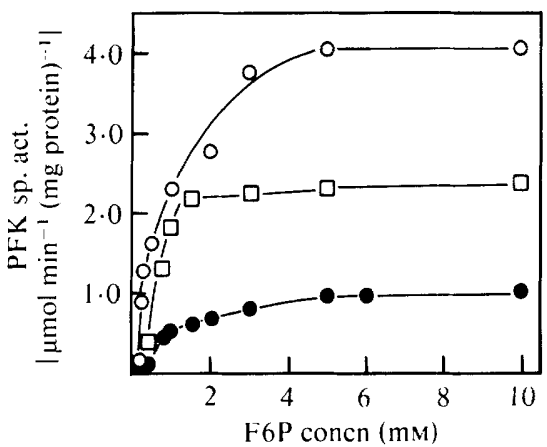

Fig. 2

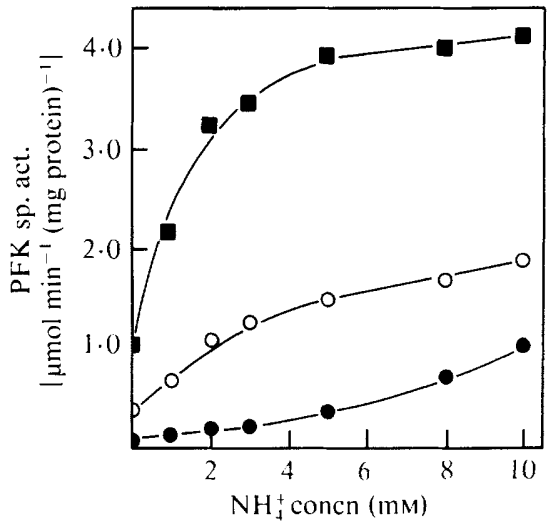

Fig. 3

Fig. 2. Effect of F6P concentration on the activity of purified PFK. Assay contained ATP at $1 \mathrm{~mm}$.

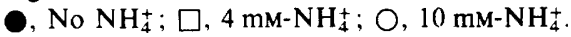

Fig. 3. Stimulation of purified PFK activity by $\mathrm{NH}_{4}^{+}$ions at varying concentrations of F6P. Assay contained $1 \mathrm{~mm}$-ATP. $0.5 \mathrm{~mm}-\mathrm{F} 6 \mathrm{P}$; O, $1 \mathrm{~mm}-\mathrm{F} 6 \mathrm{P} ; \mathbf{\square}, 5 \mathrm{~mm}-\mathrm{F} 6 \mathrm{P}$.

faint bands emerged, one close to the main band and two some distance away. These faint bands could be either contaminant proteins or sub-units of the large PFK molecule.

The apparent molecular weight $\left(M_{\mathrm{r}}\right)$ of PFK from Rs. toruloides was determined by passing a sample of the purified enzyme down a column of Sepharose 6B and comparing the elution volume with the elution volumes of standards of known molecular weight (see Methods). A plot of $\log$ mol. wt against the ratio of the elution volume to the void volume gave an apparent molecular weight $\left(M_{\mathrm{r}}\right)$ of 700000 .

The purified preparation was stable for up to $5 \mathrm{~d}$ at $-20^{\circ} \mathrm{C}$ but lost $42 \%$ activity after $6 \mathrm{~h}$ at $0{ }^{\circ} \mathrm{C}$. PFK could be stabilized by adding ATP $(1 \mathrm{mM})$, F6P $(1 \mathrm{mM})$ and $\left(\mathrm{NH}_{4}\right)_{2} \mathrm{SO}_{4}(10 \mathrm{~mm})$, either singly or in combination, and was stored at $-20^{\circ} \mathrm{C}$ in $10 \mathrm{~mm}-\left(\mathrm{NH}_{4}\right)_{2} \mathrm{SO}_{4}$ and $1 \mathrm{~mm}-\mathrm{F} 6 \mathrm{P}$ for up to 3 months without significant loss of activity. All preparations were desalted by passing down a column of Sephadex G-25 prior to studying the kinetic properties.

\section{Properties of the purified enzyme preparation}

The activity of PFK was stimulated by $\mathrm{NH}_{4}^{+}$and so all subsequent experiments were performed both in the presence and absence of $\mathrm{NH}_{4}^{+}$ions. The enzyme exhibited maximum activity between $\mathrm{pH} 7.4$ and 8.2 in $0.1 \mathrm{M}$-phosphate buffer; activity fell by $50 \%$ at $\mathrm{pH} 6.5$ and by $33 \%$ at $\mathrm{pH} 8.5$. A $\mathrm{pH}$ of 8.0 was used in all subsequent assays.

In the presence of $10 \mathrm{mM}-\mathrm{NH}_{4}^{+}$, the $V_{\text {max }}$ of PFK was increased from 1.02 to $4.23 \mu \mathrm{mol} \mathrm{mg} \mathrm{min}^{-1} \mathrm{~min}^{-1}$ (Fig. 2). The apparent $K_{\mathrm{m}}$, calculated by the usual double reciprocal plot, for F6P in the absence of $\mathrm{NH}_{4}^{+}$ions was $1.25 \mathrm{~mm}$ whereas $\mathrm{NH}_{4}^{+}$ions increased the affinity of PFK for F6P with a $K_{\mathrm{m}}$ of $0.55 \mathrm{mM}$. This conclusion was confirmed by following the effect of $\mathrm{NH}_{4}^{+}$ions on PFK activity at three concentrations of F6P (Fig. 3): with $10 \mathrm{mM}-\mathrm{NH}_{4}^{+}$, the activity of PFK was increased 4-fold with $5 \mathrm{mM}-\mathrm{F} 6 \mathrm{P}$, 5-fold with $1 \mathrm{mM}-\mathrm{F} 6 \mathrm{P}$ and 11 -fold with $0.5 \mathrm{~mm}-\mathrm{F} 6 \mathrm{P}$.

The apparent $K_{\mathrm{m}}$ for ATP in the absence of $\mathrm{NH}_{4}^{+}$ions was calculated as $0.41 \mathrm{~mm}$ and to be $0.29 \mathrm{~mm}$ in the presence of $10 \mathrm{mM}-\mathrm{NH}_{4}^{+}$. In comparison with the effect of $\mathrm{NH}_{4}^{+}$ions on the affinity of PFK for its other substrate, F6P, this is a much smaller, and perhaps insignificant, effect. Maximum activity, with or without $\mathrm{NH}_{4}^{+}$, was obtained at 1 mM-ATP; no inhibition of activity occurred at 10 times this concentration.

\section{Effect of nucleotides}

Nucleotide triphosphates other than ATP could also function in the PFK reaction though to a lesser extent than ATP (Table 3). Apparent $K_{\mathrm{m}}$ values, determined in the usual manner, in the absence of $\mathrm{NH}_{4}^{+}$ions, were $0.61 \mathrm{mM}$ for GTP, $0.69 \mathrm{mM}$ for ITP, $0.83 \mathrm{~mm}$ for CTP and $1.36 \mathrm{~mm}$ 


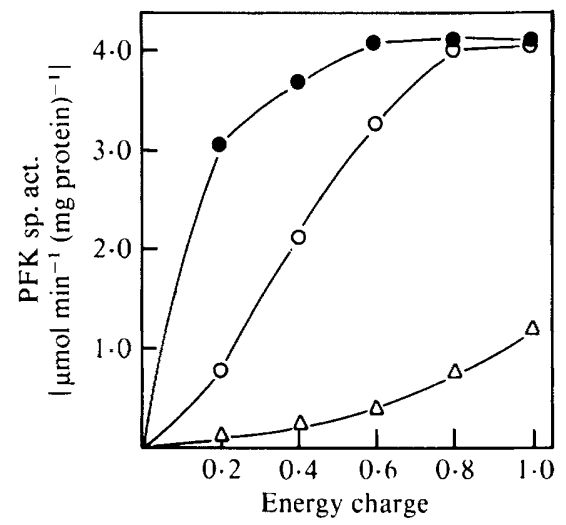

Fig. 4. Effect of energy charge on the activity of purified PFK. Assay contained $5 \mathrm{~mm}-\mathrm{F} 6 \mathrm{P}$ and $10 \mathrm{~mm}-$ $\mathrm{NH}_{4}^{+}$. Energy charge values were calculated according to Bomsel \& Pradet (1968). Total adenine nucleotide concentrations: $\triangle, 0.1 \mathrm{~mm} ; 0,1 \mathrm{~mm} ; \bigcirc, 10 \mathrm{~mm}$.

Table 3. Activity of purified PFK with various nucleotides

The standard assay was used containing $5 \mathrm{mM}$-fructose 6-phosphate and $10 \mathrm{mM}-\mathrm{NH}_{4}^{+}$ions; $100 \%$ activity $=4.4 \mu \mathrm{mol}(\mathrm{mg} \text { protein })^{-1} \mathrm{~min}^{-1}$. AMP, GMP, IMP, CMP and UMP were ineffective (nil activity) at both $1 \mathrm{mM}$ and $10 \mathrm{~mm}$.

$\begin{array}{lcc}\text { Nucleotide } & \overbrace{1 \mathrm{mM}}^{\% \text { Activity at: }} & 10 \mathrm{mM} \\ \text { ATP } & 100 & 100 \\ \text { ADP } & 12 & 31 \\ \text { GTP } & 39 & 98 \\ \text { GDP } & 4 & 20 \\ \text { ITP } & 30 & 80 \\ \text { IDP } & 4 & \text { ND } \\ \text { CTP } & 14 & 63 \\ \text { UTP } & 5 & 28 \\ \text { UDP } & 2 & 4\end{array}$

ND, Not determined.

for UTP. Nucleotide diphosphates were only partially active as substrates whilst all the nucleotide monophosphates were totally inactive.

The response of PFK to various combinations of adenine nucleotides, to give various simulated energy charge values (cf. Atkinson, 1977), was determined (Fig. 4) as these are probably more important than the effects of the individual nucleotides. The activity of PFK depended upon the total concentration of adenine nucleotides being used. With the lowest concentration, $0.1 \mathrm{mM}$, which was much below the saturating substrate concentration of the enzyme (for ATP), the activity appeared to be limited by the availability of the substrate. With $1.0 \mathrm{~mm}$-nucleotides, maximum activity was attained at an energy charge of 0.8 . With $10 \mathrm{~mm}$-nucleotides, high activity of PFK (greater than $75 \%$ maximum) occurred at all energy charge values tested. There was no evidence that ADP, or AMP, either inhibited or stimulated the activity.

\section{Effect of various metabolites}

Other likely modulators of PFK activity, besides ATP and $\mathrm{NH}_{4}^{+}$ions, were tested at $10 \mathrm{~mm}$ both alone and in the presence of $20 \mathrm{mM}-\mathrm{NH}_{4}^{+}$. With $\mathrm{K}^{+}$ions, in the absence of $\mathrm{NH}_{4}^{+}$, activity increased to $139 \%$, but with $\mathrm{NH}_{4}^{+}$present no stimulation was evident. PFK was severely inhibited in the absence of $\mathrm{NH}_{4}^{+}$ions by the tricarboxylic acids, isocitrate, cis-aconitate and citrate, having activities of 12,14 and $15 \%$, respectively, of the control. In the presence of $\mathrm{NH}_{4}^{+}$ these inhibitions were alleviated to give activities of 79,80 and $88 \%$, respectively. Fructose 


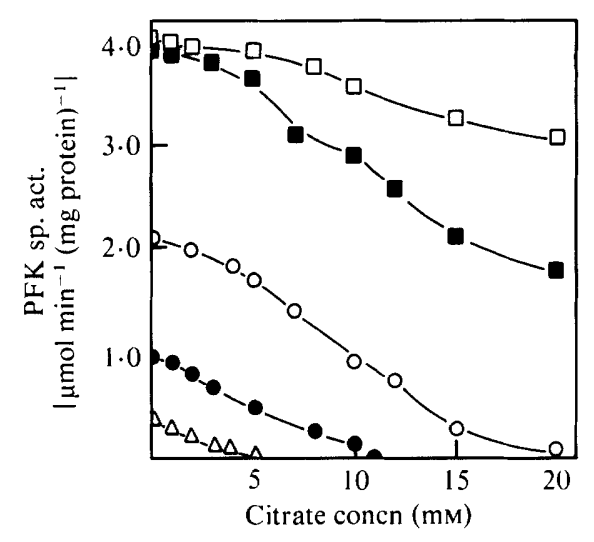

Fig. 5. Effect of citrate on the activity of purified PFK. Assays contained: $\triangle, 1 \mathrm{mM}-\mathrm{F} 6 \mathrm{P}+$ no $\mathrm{NH}_{4}^{+}$; , $5 \mathrm{~mm}-\mathrm{F} 6 \mathrm{P}+$ no $\mathrm{NH}_{4}^{+} ; \mathrm{O}, 5 \mathrm{~mm}-\mathrm{F} 6 \mathrm{P}+1 \mathrm{mM}^{-\mathrm{NH}_{4}^{+} ;}, 5 \mathrm{~mm}-\mathrm{F} 6 \mathrm{P}+8 \mathrm{mM}^{-\mathrm{NH}_{4}^{+}} ; \square, 5 \mathrm{~mm}-\mathrm{F} 6 \mathrm{P}+$ $20 \mathrm{mM}-\mathrm{NH}_{4}^{+}$.

1,6-bisphosphate was the only other metabolite to result in any inhibition; this, though, was slight: $88 \%$ of the control in the absence of $\mathrm{NH}_{4}^{+}$and $92 \%$ in its presence. Malate, oxaloacetate, pyruvate, 2-oxoglutarate, glucose 6-phosphate, glucose 1-phosphate, glutamate, aspartate, acetate, acetyl-CoA, CoA and $\mathrm{Na}^{+}$had no effect on activity either in the absence or presence of $\mathrm{NH}_{4}^{+}$.

\section{Inhibition by citrate}

As citrate plays a key role in lipogenesis in oleaginous yeasts including $R s$. toruloides, we investigated its effect on PFK in more detail (Fig. 5). In the absence of $\mathrm{NH}_{4}^{+}$, the activity of the enzyme quickly diminished with increasing concentrations of citrate. Even in the presence of $1 \mathrm{mM}-\mathrm{NH}_{4}^{+}$and $5 \mathrm{~mm}-\mathrm{F} 6 \mathrm{P}$, citrate was still a strong inhibitor, giving $58 \%$ inhibition at $10 \mathrm{~mm}$. When the $\mathrm{NH}_{4}^{+}$concentration was increased to $8 \mathrm{mM}$, the inhibition by citrate dropped to $28 \%$ and at $20 \mathrm{~mm}-\mathrm{NH}_{4}^{+}$, PFK was only inhibited by $10 \%$.

From a Lineweaver-Burk plot this inhibition of PFK by citrate was found to be competitive with F6P in the absence of $\mathrm{NH}_{4}^{+}$ions; the $K_{\mathrm{i}}$ values for citrate were calculated as $1.0 \mathrm{mM}$ with zero $\mathrm{NH}_{4}^{+}$ions and $7.2 \mathrm{~mm}$ in the presence of $10 \mathrm{mM}-\mathrm{NH}_{4}^{+}$.

\section{The effect of fatty acyl-CoA esters}

Both mitochondrial citrate efflux (Evans et al., 1983) and ATP : citrate lyase (Boulton \& Ratledge, 1981, 1983b) in oleaginous yeasts have been shown to be extremely sensitive to inhibition by long chain fatty acyl-CoA esters (FACEs). It was therefore thought that PFK might also be susceptible to feedback inhibitory control by these molecules. With FACEs at $10 \mu \mathrm{M}$ little inhibition was observed: palmitoyl-CoA inhibited activity only by $16 \%$; stearoyl-CoA, oleoylCoA and myristoyl-CoA gave 9 to $10 \%$ inhibition; lauroyl-CoA gave $5 \%$ inhibition and acetyl$\mathrm{CoA}$ and malonyl-CoA both gave none at all. Palmitoyl carnitine and methyl palmitate gave negligible inhibitions ( $4 \%$ and $3 \%$, respectively). At $100 \mu \mathrm{M}$, FACEs gave more pronounced inhibitions: palmitoyl-CoA, myristoyl-CoA, stearoyl-CoA, oleoyl-CoA and lauroyl-CoA inhibited activity by $77,53,49,40$ and $28 \%$, respectively. However, as the critical micelle concentration of palmitoyl-CoA is about $3 \mu \mathrm{M}$ (see Boulton \& Ratledge, 1983b), the inhibitions induced by the higher concentrations of FACEs are probably not of physiological significance.

\section{DISCUSSION}

The growth of Rs. toruloides CBS 14 in the presence of $\mathrm{NH}_{4}^{+}$causes the glucose substrate to be channelled preferentially into carbohydrate (mainly glycogen) rather than lipid, even though the cells contain the necessary enzymes for lipid accumulation. By following the uptake of ${ }^{14} \mathrm{C}$ labelled glucoses, we were able to deduce that there is some impediment to the flow of glucose 
Table 4. Comparison of phosphofructokinase from yeasts

\begin{tabular}{|c|c|c|c|}
\hline & S. cerevisiae & Rt. glutinis & Rs. toruloides (this paper) \\
\hline$M_{\mathrm{r}}$ & $835000(1)$ & - & 700000 \\
\hline$K_{\mathrm{m}}(\mathrm{F} 6 \mathrm{P})$ & $0.26 \mathrm{~mm}(2)$ & $\begin{array}{c}0.55 \mathrm{mM} \mathrm{(3)} \\
50 \mathrm{mM} \mathrm{(4)} \\
>3 \mathrm{mM} \mathrm{(5)}\end{array}$ & $\begin{array}{l}0.55 \mathrm{~mm} \text { in presence of } \mathrm{NH}_{4}^{+} \\
1.25 \mathrm{~mm} \text { in absence of } \mathrm{NH}_{4}^{+}\end{array}$ \\
\hline$K_{\mathrm{m}}(\mathrm{ATP})$ & $0.033 \mathrm{~mm}(2)$ & $15 \mathrm{~mm}(3)$ & $0.3-0.4 \mathrm{~mm}$ \\
\hline $\mathrm{pH}$ optimum & $7 \cdot 8-8 \cdot 2(2)$ & $8 \cdot 0(3)$ & $8 \cdot 0$ \\
\hline Inhibition by ATP & Yes, at $0.1-0.5 \mathrm{~mm}(2,7,9)$ & No $(3,4,6)$ & None up to $10 \mathrm{~mm}$ \\
\hline Inhibition by ADP & Yes, at $0.5 \mathrm{~mm}(8)$ & Yes, at $100 \mathrm{~mm}(4)$ & None up to $10 \mathrm{~mm}$ \\
\hline Inhibition by citrate & Yes (7) & ? & Yes \\
\hline Stimulation by $\mathrm{NH}_{4}^{+}$ & Yes $(8,9)$ & $?$ & Yes \\
\hline
\end{tabular}

References: (1) Kopperschläger et al. (1977); (2) Lindell \& Stellwagen (1968); (3) Mazon et al. (1974); (4) Zeidan (1981); (5) Batrons et al. (1982); (6) Doelle \& Hollywood (1977); (7) Salas et al. (1965); (8) Atzpodien \& Bode (1970); (9) Mavis \& Stellwagen (1970).

through to acetyl-CoA in these cells; this restriction is removed either when cells are grown with an organic nitrogen source (e.g. glutamate) or when such a nitrogen source is added to washed cell suspensions. As our previous studies have shown that organic nitrogen sources rapidly engender high intracellular concentrations of $\mathrm{NH}_{4}^{+}$, but $\mathrm{NH}_{4}^{+}$itself does not (Evans \& Ratledge, $1984 a, b$ ), we concluded that the most likely explanation for our observations was that $\mathrm{NH}_{4}^{+}$ions were regulating the activity of a key enzyme of glycolysis: the most likely candidate being PFK.

PFK was originally thought to be absent in high lipid-producing species of Rhodotorula and Candida 107 (Brady \& Chambliss, 1967; Höfer et al., 1969, 1971; Whitworth \& Ratledge, 1975). It was eventually detected in the red yeast Rhodotorula glutinis and Candida 107 using the toluene permeabilization method of Serrano et al. (1973) and shown to be extremely labile (Mazon et al., 1974; Ratledge \& Botham, 1977). The enzyme we have isolated from Rhodosporidium toruloides CBS 14 showed a similar lability in extracts prepared from nitrogen-limited cells but was stable when isolated from cells grown with an excess of nitrogen. The former extracts were found to contain a protease which appeared relatively specific for PFK and could thus account for the low activities of PFK which are sometimes reported (e.g. Zeiden, 1981) and for the previous failures to find this enzyme in the Rhodotorula. A similar protease has been identified in extracts of S. cerevisiae (Diezel et al., 1973), though in this case the subunits of the octameric PFK complex were partially hydrolysed without rendering the enzyme inactive (Kopperschläger et al., 1977). Whether this protease in $R s$. toruloides fulfils a regulatory role in controlling PFK activity remains unclear at this stage.

The molecular size of PFK from Rs. toruloides was 700000 , which is slightly less then the $835000 \pm 32000$ calculated for the enzyme from $S$. cerevisiae (Kopperschläger et al., 1977). Previous estimates of 500000 to 600000 for the size of the enzyme (see Uyeda, 1979) are considered to be of proteolytically modified forms which occur by losses of $24000 M_{\mathrm{r}}$ fragments from each of the eight subunits. Whilst it is possible that similar proteolysis occurred in the present study, it does not appear to have affected the response of the purified enzyme to various effectors in vitro. Although the preparation of PFK had been considerably purified, it had only about $5 \%$ of the specific activity of the PFK purified to homogeneity from bakers' yeast (Diezel et al., 1973).

A comparison of the other properties of PFK from Rs. toruloides with those of the related $R t$. glutinis and Saccharomyces cerevisiae show some important differences as well as similarities (see Table 4). The most important difference between the PFK from Rs. toruloides and that from bakers' yeast was that the former enzyme showed no inhibition by either ATP or ADP up to $10 \mathrm{mM}$. Both PFKs, however, were activated by $\mathrm{NH}_{4}^{+}$, which significantly increased the affinity of the enzyme for both its substrates. The PFK from bakers' yeast was stimulated 20-fold in the presence of $80 \mathrm{~mm}-\mathrm{NH}_{4}^{+}$(Mavis \& Stellwagen, 1970) and although, in our case, the stimulation was less (4-fold) it was achieved by significantly less $\mathrm{NH}_{4}^{+}(10 \mathrm{mM})$. The enzyme from $R s$. toruloides was competitively inhibited by citrate and again this has been reported for PFK enzymes 


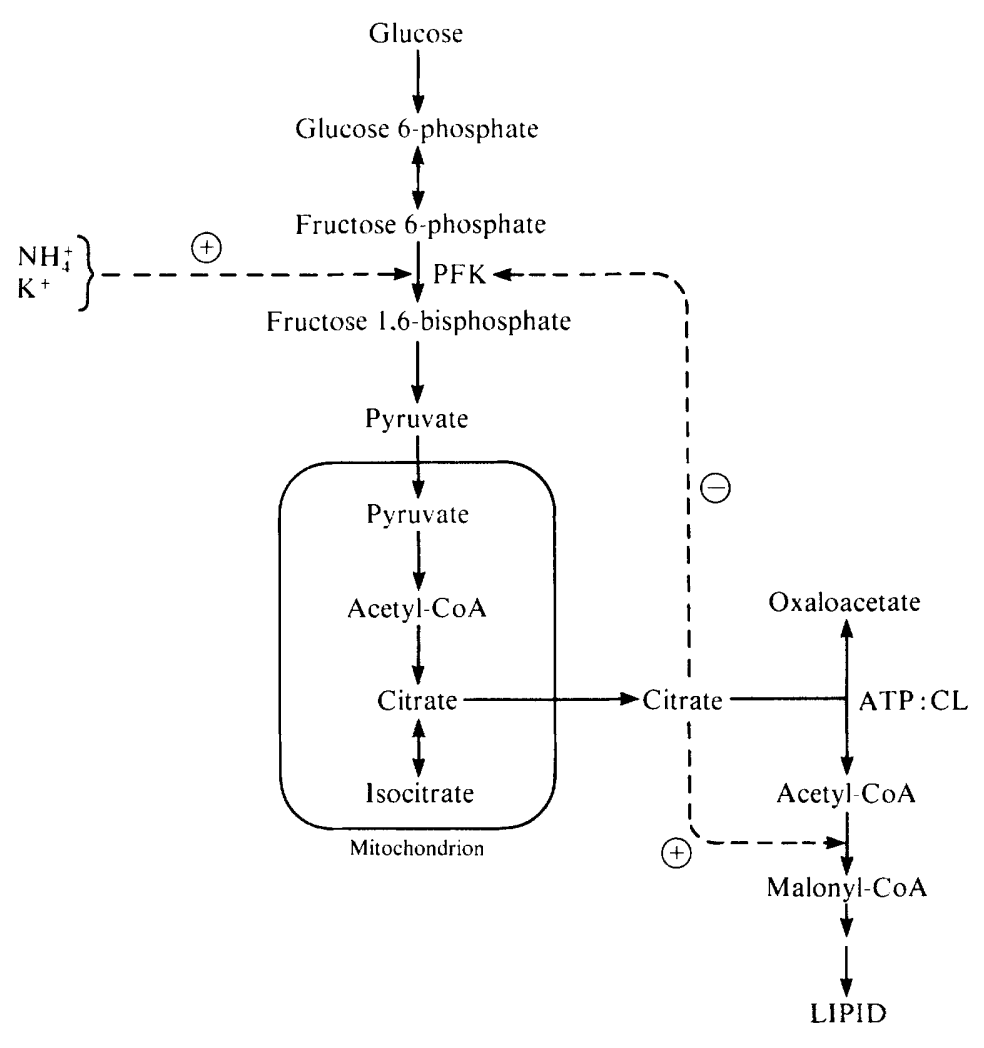

Fig. 6. Role of PFK in lipid accumulation in Rs. toruloides CBS 14. + and - indicate action of positive and negative effectors. ATP : citrate lyase (ATP:CL) is the rate-limiting step of fatty acid biosynthesis (Boulton \& Ratledge, 1981), therefore citrate will accumulate to a high steady-state concentration before lipid accumulation begins. Citrate will then inhibit PFK, thus channelling glucose into carbohydrate. However, if the intracellular concentration of $\mathrm{NH}_{4}^{+}$is high, as when an organic nitrogen source is used in the medium, this inhibition can be relieved. Under such circumstances, glucose is now converted to lipid. The metabolism of citrate through the citric acid cycle is prevented by the requirement of isocitrate dehydrogenase for AMP (Botham \& Ratledge, 1979), which is at a low concentration in lipid-accumulating cells (Boulton \& Ratledge, 1983a). Citrate, in addition to inhibiting PFK, may also serve to stimulate acetyl-CoA carboxylase (see Botham \& Ratledge, 1979).

from other yeasts and micro-organisms (Salas et al., 1965; Rohr \& Kubicek, 1981). It is, however, the interrelationship between the inhibition by citrate and the relief of this inhibition by $\mathrm{NH}_{4}^{+}$which we consider to be the key regulatory event which can then explain lipid accumulation in this oleaginous yeast when grown with different nitrogen sources (Evans \& Ratledge, 1984a, $b$ ).

From our previous data (Evans \& Ratledge, 1984a) it can be calculated that in Rs. toruloides CBS 14, the intracellular citrate concentrations increased from approx. $2 \mathrm{~mm}$ to $8 \mathrm{~mm}$, between 20 and $40 \mathrm{~h}$ growth, in both glutamate- and urea-grown cells (values calculated assuming an intracellular water space of $2 \mu \mathrm{l}$ per mg dry weight; Knowles, 1977). It is difficult to ascertain the significance of these concentrations because of compartmentation within the cell but the excretion of citrate into the medium before lipid starts to accumulate suggests that the cytosolic pool of citrate has reached its maximum concentration (Evans \& Ratledge, 1984 $b$; see also Boulton \& Ratledge, 1983a). The actual cytosolic concentration of citrate in the vicinity of PFK could be much greater than 2 to $8 \mathrm{~mm}$ because the intracellular aqueous volume will be decreased by the expanding size of the lipid globules which can account for half the cell volume (Evans \& Ratledge, 1984a). 
If we assume intracellular citrate concentrations could be as high as $10 \mathrm{mM}$, then PFK activity would be completely inhibited as the actual substrate (F6P) concentration will probably be very low throughout growth (the concentration of glucose 6-phosphate, with which F6P will be in equilibrium, was usually about $10 \%$ of the citrate concentration in these cells - Evans \& Ratledge, 1984a). However, the intracellular $\mathrm{NH}_{4}^{+}$concentration reaches $15 \mathrm{mM}$ after $30 \mathrm{~h}$ growth on glutamate (Evans \& Ratledge, $1983 a, b$ ) which would ensure almost maximum PFK activity even in the presence of this amount of citrate (see Fig. 6). From the work of Boulton \& Ratledge (1983a) and Botham \& Ratledge (1979) a value of about $1 \mathrm{mM}$ can be calculated for the concentrations of ATP within oleaginous yeasts. This would be a sufficient concentration, if also present in Rs. toruloides, not to be limiting PFK activity during lipogenesis.

This type of regulation of $\mathrm{PFK}$ in vivo by $\mathrm{NH}_{4}^{+}$ions is similar to that reported in other systems (Abrahams \& Younathan, 1971; Bloxham \& Lardy, 1973; Lloyd et al., 1983) and for the citric acid-producing aspergilli (Habison et al., 1983; Rohr \& Kubicek, 1981) where very high concentrations of intracellular $\mathrm{NH}_{4}^{+}$ions (between $25 \mathrm{~mm}$ and $15 \mathrm{mM}$ ) prevail throughout growth providing constant alleviation of citrate inhibition. We conclude, therefore, that when $\mathrm{NH}_{4}^{+}$is used as nitrogen source with $R$ s. toruloides and the intracellular concentration of $\mathrm{NH}_{4}^{+}$is low (Evans \& Ratledge, 1984a), PFK is readily inhibited by citrate. Clearly, some glucose is metabolized through PFK in order to maintain the tricarboxylic acid cycle and the citric acid pool. Even when cells have exhausted the supply of nitrogen and lipid accumulation may be expected to occur, PFK continues to be inhibited. Consequently incoming glucose is now diverted into the only other storage material possible - carbohydrate. Such cells could be described as exhibiting the properties of the classical Pasteur effect, whereby glycolysis is restricted and carbohydrate reserves build up (Sols et al., 1971).

When cells are grown with an organic nitrogen source, such as glutamate or urea, the intracellular $\mathrm{NH}_{4}^{+}$concentration is high during the first $40 \mathrm{~h}$ growth (Evans \& Ratledge, 1984a), PFK is fully active and lipid accumulation can then commence. However, although our present observations explain how lipid accumulation takes place during the first $40 \mathrm{~h}$ they do not provide an explanation for its continued synthesis after this time when it would be expected that the ameliorating effect of $\mathrm{NH}_{4}^{+}$on citrate inhibition of PFK would disappear after exhaustion of the nitrogen source. The findings of Mavis \& Sellwagen (1970), however, show that the PFK from $S$. cerevisiae forms two complexes with $\mathrm{NH}_{4}^{+}$; if the enzyme from $R s$. toruloides were to form similar complexes these may persist after the depletion of the intracellular $\mathrm{NH}_{4}^{+}$pool thus ensuring continued insensitivity to citrate inhibition. Whatever the explanation, the metabolic machinery of the cell, which includes PFK, becomes 'locked-in' during the first $40 \mathrm{~h}$ growth so that subsequent changes in concentrations of key metabolites do not then deflect the cell from subsequently accumulating lipid.

This work was supported by a Co-operative Award in Science and Engineering from the Science and Engineering Research Council in conjunction with Cadbury-Schweppes plc.

\section{REFERENCES}

Abrahams, S. L. \& Younathan, E. S. (1971). Modulation of the kinetic properties of phosphofructokinase by ammonium ions. Journal of Biological Chemistry 246, 2464-2467.

Atkinson, D. E. (1977). Cellular Energy Metabolism and its Regulation. New York, San Francisco \& London: Academic Press.

Atzpodien, W. \& Bode, H. (1970). Purification and regulatory properties of ATP-sensitive phosphofructokinase from yeast. European Journal of Biochemistry 12, 126-132.

Bartrons, R., Van Schaftingen, E., Vissers, S. \& HERS, H. G. (1982). The stimulation of yeast phosphofructokinase by fructose 2,6-bisphosphate. FEBS Letters 143, 137-140.
Blinc, M. \& Hočevar, B. (1953). Fettanreicherung on Rhodotorula gracilis. Monatshefte für Chemie und verwandte Teile anderer Wissenschaften 84, 1127 1131.

Bloxham, D. P. \& Lardy, H. A. (1973). Phosphofructokinase. In The Enzymes, vol. 8, 3rd edn, pp. 239-278. Edited by P. D. Boyer. New York: Academic Press

Bomsel, J. -L. \& Pradet, A. (1968). Study of adenosine 5 -mono, di and triphosphates in plant tissues. Regulation of the level of nucleotides, in viro, by adenylate kinase: theoretical and experimental study. Biochimica et biophysica acta 162, 230242.

Botham, P. A. \& Ratledge, C. (1979). A biochemical 
explanation for lipid accumulation in Candida 107 and other oleaginous micro-organisms. Journal of General Microbiology 114, 361-375.

Boulton, C. A. \& Ratledge, C. (1981). Correlation of lipid accumulation in yeasts with possession of ATP : citrate lyase. Journal of General Microbiology 127, 169-176.

Boulton, C. A. \& Ratledge, C. (1983a). Use of transition studies in continuous cultures of Lipomyces starkeyi, an oleaginous yeast, to investigate the physiology of lipid accumulation. Journal of General Microbiology 129, 2871-2876.

Boulton, C. A. \& Ratledge, C. (1983b). Partial purification and some properties of ATP:citrate lyase from the oleaginous yeast Lipomyces starkeyi. Journal of General Microbiology 129, 2863-2869.

BRADFORD, M. M. (1976). A rapid and sensitive method for the quantitation of microgram quantities of protein utilizing the principle of protein-dye binding. Analytical Biochemistry 72, 248-254.

Brady, R. J. \& Chambliss, G. H. (1967). The lack of phosphofructokinase activity in several species of Rhodotorula. Biochemical and Biophysical Research Communications 29, 898-903.

Davis, B. J. (1964). Disc electrophoresis. II. Method and application to human serum proteins. Annals of the New York Academy of Sciences 121, 404-427.

Diezel, W., Bohme, H. -J., Nissler, C., Freyer, R., HeilmanN, W., KopperschläGer, G. \& HofmanN, E. (1973). A new purification procedure for yeast phosphofructokinase minimizing proteolytic degradation. European Journal of Biochemistry 38, 479488.

Doelle, H. W. \& Hollywood, N. (1977). The occurrence and distribution of two phosphofructokinase proteins in the facultative anaerobic family of enterobacteriaceae. FEMS Letters 1, 31-34.

Evans, C. T. \& Ratledge, C. (1983). Biochemical activities during lipid accumulation in Candida curvata. Lipids 18, 630-635.

Evans, C. T. \& Ratledge, C. (1984a). Effect of nitrogen source on lipid accumulation in oleaginous yeasts. Journal of General Microbiology 130, 16931704.

Evans, C. T. \& Ratledge, C. (1984b). Influence of nitrogen metabolism on lipid accumulation by Rhodosporidum toruloides CBS 14. Journal of General Microbiology 130, 1705-1710.

Evans, C. T., ScragG, A. H. \& Ratledge, C. (1983). Regulation of citrate efflux from mitochondria of oleaginous and non-oleaginous yeasts by long-chain fatty acyl-CoA esters. European Journal of Biochemistry 132, 617-622.

FraENKEL, D. C. (1982). Carbohydrate metabolism. In The Molecular Biology of the Yeast Saccharomyces: Metabolism and Gene Expression, pp. 1-37. Edited by J. N. Strathern, E. W. Janes \& J. R. Broach. New York: Cold Spring Harbor Laboratory.

Gunja-Smith, Z., PAtil, N. B. \& Smith, E. E. (1977). Two pools of glycogen in Saccharomyces. Journal of Bacteriology 130, 818-825.

Habison, A., Kubicek, C. P. \& Rohr, M. (1983). Partial purification and regulatory properties of phosphofructokinase from Aspergillus niger. Biochemical Journal 209, 669-676.

Herbert, D., Phipps, P. J. \& Strange, R. E. (1971)
Chemical analysis of microbial cells. Methods in Microbiology 5B, 209-344.

HöFer, M., BeCKer, J.-U., Brand, K., DeCKNer, H \& BETZ, A. (1969). A study of the enzyme equipment of the yeast Rhodotorula gracilis. FEBS Letters 3, 322-324.

Hö Fer, M., Brand, K., Deckner, H. \& Becker, J.-U (1971). Importance of the pentose phosphate pathway for D-glucose catabolism in the obligatory aerobic yeast Rhodotorula gracilis. Biochemical Journal 123, 855-863.

Holzer, H., Betz, H. \& Ebner, E. (1975). Intracellular proteinases in micro-organisms. Current Topics in Cellular Regulation 9, 103-156.

Hughes, D. E., Wimpenny, J. W. T. \& Lloyd, D. (1971). The disintegration of micro-organisms. Methods in Microbiology 5B, 1-54.

KNOWLES, C. J. (1977). Microbial metabolic regulation by adenine nucleotide pools. Symposia of the Society for General Microbiology 27, 241-283.

KoppersChläGER, G., Bar, J., NisSler, K. \& HofMANN, E. (1977). Physicochemical parameters and subunit composition of yeast phosphofructokinase. European Journal of Biochemistry 81, 317-325.

Lindell, T. J. \& Stellwagen, E. (1968). Purification and properties of phosphofructokinase from yeast. Journal of Biological Chemistry 243, 907-912.

Lloyd, D., Kristensen, B. \& Degn, H. (1983). Glycolysis and respiration in yeasts: the effect of ammonium ions studied by mass spectrometry. Journal of General Microbiology 129, 2125-2127.

Mavis, R. D. \& Stellwagen, E. (1970). The role of cations in yeast phosphofructokinase catalysis. Journal of Biological Chemistry 245, 674-680.

Mazon, M. J., GanCEdo, J. M. \& Gancedo, C. (1974). Identification of an unusual phosphofructokinase in the red yeast Rhodotorula glutinis. Biochemical and Biophysical Research Communications 61, 13041309.

Ratledge, C. \& Botham, P. A., (1977). Pathway of glucose metabolism in Candida 107, a lipid-accumulating yeast. Journal of General Microbiology 102 , 391-395.

RoHR, M. \& KUBICEK, C. P. (1981). Regulatory aspects of citric acid fermentation by Aspergillus niger. Process Biochemistry 16 (no. 4), 34-37 (+44).

Salas, M. L., Vinuela, E., Salas, M. \& Sols, A (1965). Citrate inhibition of phosphofructokinase and the Pasteur effect. Biochemical and Biophysical Research Communications 19, 371-376.

Serrano, R., Gancedo, J. M. \& Gancedo, C. (1973). Assay of yeast enzymes in situ. A potential tool in regulation studies. European Journal of Biochemistry 34, 479-482.

Sols, A. \& Salas, M. L. (1966). Phosphofructokinase. Methods in Enzymology 9, 436-442.

Sols, A., Gancedo, C. \& Delafuente, G. (1971). Energy-yielding metabolism in yeasts. In The Yeasts, vol. 2, pp. 271-308. Edited by A. H. Rose. London: Academic Press.

Trevelyan, W. E. \& Harrison, J. S. (1956). Studies on yeast metabolism. Biochemical Journal 63, 23-33.

UYEDA, K. (1979). Phosphofructokinase. Advances in Enzymology 48, 193-244.

Whitworth, D. A. \& Ratledge, C. (1975). An analysis of intermediary metabolism and its control 
in a fat-synthesizing yeast (Candida 107) growing on glucose or alkanes. Journal of General Microbiology 88, 275-288.

Witter, B., Debuch, H. \& Steiner, M. (1974). Die Lipide von Endomycopsis vernalis bei verschiedener Stickstoff-Ernährung. Archives of Microbiology 101, 321-335.
Wood, H. C., Katz, J. \& Landau. B. R. (1963). Estimation of pathways of carbohydrate metabolism. Biochemische Zeitschrift 338, 809-847.

ZeIDAN, H. M. (1981). Purification and characterization of phosphofructokinase from Rhodotorula glutinis. Biochemical and Biophysical Research Communications 100, 681-687. 